\title{
Whole Lung Irradiation in Patients with Osteosarcoma and Ewing Sarcoma
}

\author{
LETIZIA RONCHI $^{1}$, MILLY BUWENGE ${ }^{1}$, ANNALISA CORTESI ${ }^{2}$, ILARIO AMMENDOLIA ${ }^{1}$, \\ REZARTA FRAKULLI ${ }^{1}$, MASSIMO E. ABATE ${ }^{3}$, ALESSANDRA ARCELLI $^{1}$, COSTANZA M. DONATI $^{1}$, \\ GABRIELLA MACCHIA $^{4}$, ALESSIO G. MORGANTI ${ }^{1 *}$ and SILVIA CAMMELLI ${ }^{1 *}$ \\ ${ }^{1}$ Radiation Oncology Center, Department of Experimental, Diagnostic and Speciality Medicine -DIMES, \\ S. Orsola-Malpighi Hospital, University of Bologna, Bologna, Italy; \\ ${ }^{2}$ Istituto Scientifico Romagnolo per lo Studio e la Cura dei Tumori (I.R.S.T.) S.r.l. Sede legale, Meldola, Italy; \\ ${ }^{3}$ Chemotherapy Section, Istituto Ortopedico Rizzoli , Bologna, Italy; \\ ${ }^{4}$ Radiotherapy Unit, Department of Oncology, "Giovanni Paolo II" Foundation, \\ Catholic University of Sacred Heart, Campobasso, Italy
}

\begin{abstract}
Background/Aim: Whole lung irradiation (WLI) represents standard therapy for patients with pulmonary metastases from Ewing sarcoma although the impact on clinical outcomes and toxicity is still unclear. The aim of this study was to evaluate toxicity after WLI in patients with Ewing sarcoma and osteosarcoma as well as overall survival (OS) and event-free survival (EFS). Materials and Methods: A systematic review of studies on bilateral pulmonary irradiation treatments for prophylactic or curative therapy was performed based on PRISMA methodology. Data base searches on PubMed and Cochrane Library from the earliest time possible through 31st March 2018 were carried out. Combination with other treatments, such as chemotherapy and surgery were allowed. Only articles published in English were considered. Results: Toxicity was evaluated in 13 of the 14 analyzed studies (640 patients). Reported lung acute toxicity grade $\geq 3$ ranged between 0.0 and $12.2 \%$. Three studies reported 12 cases (1.8\%) of severe pneumonitis. Grade $\geq 2$ late toxicity was mainly recorded in patients who received boost irradiation, previous thoracic surgery, chemotherapy or who
\end{abstract}

This article is freely accessible online.

*These Authors contributed equally to this study.

Correspondence to: Milly Buwenge MSc, Department of Experimental, Diagnostic and Speciality Medicine - DIMES, University of Bologna, S. Orsola-Malpighi Hospital, via Giuseppe Massarenti 9, 40138, Bologna, Italy. Tel: +39 0516363136, Fax: +390516364336, e-mail: mbuwenge@gmail.com.

Key Words: Whole lung, Ewing, sarcoma, radiation therapy, review. were smokers. Lack of a significant impact of WLI on OS was reported in comparative studies although patients treated with WLI showed higher survival in most individual studies. Conclusion: Although the rate of severe toxicity was very low, the real impact of WLI on patients' outcomes remains unproven, probably due to the narrow dose limits that can be delivered to the whole lung parenchyma. New strategies to prevent or treat lung metastases in these patients should be tested. Ultra-fractionated radiotherapy concurrent with modern chemotherapy protocols could be tested in this setting due to the chemo-sensitizing effect and negligible radioinduced toxicity of fraction doses $<0.5 \mathrm{~Gy}$.

Primary bone and joints malignancies are ranked as the third leading cause of cancer-related death in patients younger than 20 years old and account for approximately $0.2 \%$ of all malignancies (1). From 0.9 (United States) to 1.44 (China), new bone tumor cases are diagnosed per 100,000 persons/ year $(2,3)$. In $90 \%$ of cases, primary bone tumors are diagnosed in children and young adults (2), and the lung is the most common site of metastatic involvement followed by bone (3).

Whole lung irradiation (WLI) has been demonstrated beneficial in several pediatric tumors with propensity for lung metastases (3). Furthermore, WLI has been pivotal since 1969 in the treatment of lung metastases for patients with primitive bone sarcoma and particularly Ewing Sarcoma (ESa) (4) despite reported severe toxicities $(5,6)$. Two initial randomized trials in the pre-chemotherapy (CT) era showed improved outcomes with WLI $(7,8)$. Subsequently, the results of the EORTC/SIOP (7) phase III trial which enrolled 240 patients with localized bone sarcoma randomized in 
three arms: CT, WLI (20 Gy), or both were published. No significant differences between arms were reported in terms of outcomes (7). Based on these results, WLI was progressively less used as reported in a non-systematic narrative literature review published in 2002 (9).

However, WLI is still included in international guidelines as a treatment option in patients with pulmonary metastases from ESa despite conflicting results $(8,10,11)$ of randomized trials. Therefore, the aim of this study was to systematically review, based on the PRISMA methodology (12), the available evidence on WLI results in terms of treatment-related toxicity and clinical outcomes.

\section{Materials and Methods}

Inclusion criteria. Prospective and retrospective studies on WLI as curative, palliative, or prophylactic therapy were included. Only studies enrolling patients with sarcoma of the bone (ESa or osteosarcoma (OSa)) with or without pulmonary metastases at time of diagnosis were included in this analysis. Studies on WLI combined with CT and/or surgery were not excluded. Less than 10 study participants, case-reports, editorials, letters, reviews and planning studies were excluded. Only studies published in English were considered. Furthermore, external beam radiotherapy (RT) studies irrespective of technique, dose and fractionation that targeted both lungs were assessed for inclusion. Concurrent or sequential and single or multiple drug CT regimens were eligible. Up-front metastasectomy or metastasectomy of lung nodules not completely responding to WLI +/- CT was allowed.

Outcome measures. The primary outcome was treatment-related lung toxicity. The secondary objectives were pulmonary functional test (PFT), event-free survival (EFS), pulmonary relapse rates (PRR) and overall survival (OS)

Search methods for identification of studies. Literature search in PubMed database and Cochrane Library to select studies up to 31 st March 2018 was performed. PubMed search details were (whole [All Fields] AND ("lung"[MeSH Terms] OR "lung"[All Fields]) AND ("radiotherapy"[MeSH Terms] OR "radiotherapy"[All Fields] OR "irradiation"[All Fields])) AND ("sarcoma"[All Fields] OR "Ewing"[All Fields]).

Trial selection and quality assessment. Titles and abstract screening, selection of studies, full text retrieval and data extraction were independently carried out by two authors (LR, AC) and any disagreements were resolved by the senior author (AGM). The following data from each study were obtained: authors and year of publication, medical center, Country, number of patients, median RT dose and fractionation, inclusion criteria, CT regimens, surgical treatment of metastases, PFT, risk factors related to lung toxicity, lung acute and late toxicity, EFS, PRR, and OS. Quality assessment of the selected studies was performed using the Cochrane Risk of Bias (ROB) tool.

Our systematic review protocol was registered in the International Prospective Register of Systematic Reviews (PROSPERO, www.crd.york.ac.uk/prospero/) on April 2017 (registration number: CRD42017062604).

\section{Results}

Description of studies. From the literature search, 107 studies were from PubMed, 25 from Cochrane library and 5 from other manual searched reference lists. A total of 14 full text articles including 696 patients met the established inclusion criteria and were analyzed (Figure 1). The studies were mainly conducted in Europe and USA. Five studies were randomized controlled trials $(7,8,10,11,13), 3$ were phase I/II studies $(5,14,15), 3$ were phase II trials (16-18) and 3 were retrospective series (19-21). Three studies $(17,18,22)$ were considered at low risk of bias while 6 studies were considered at high to serious risk of bias $(5,7,10,11,15,16)$.

\section{Type of Interventions}

Radiotherapy. In ten studies $(7,8,10,11,14,16-20)$, total RT prescribed doses ranged from 12 to $20 \mathrm{~Gy}$ in daily dose per fraction between 1.5 to $2.0 \mathrm{~Gy}$ using LINACs or Cobalt60 units. Two studies $(19,20)$ reported different fractionation of 1.25 and $1.5 \mathrm{~Gy}$ delivered twice a day in some patients. Marinova and colleagues reported 12-15 Gy total RT dose delivered to bilateral lungs adapted to children's age without mentioning dose per fraction (21). In one study, WLI was administered with a total dose ranging from 22.5 to $27 \mathrm{~Gy}$ delivered in 6-16 weeks (13). WLI aim was prophylactic in 10 trials $(7,8,10,11,13,14,16-18)$ and curative in 4 series $(5,15,19,20)$. Air correction for increased radiation transmissibility was performed in two studies $(7,16)$. Air correction was not carried out in 3 studies $(8,18,21)$ and this issue was not mentioned in the other papers.

Chemotherapy. Different multidrug schedules were used: (i) mitomycin $\mathrm{C}$, vincristine, doxorubicin, dacarbazine and cyclophosphamide (18); (ii) high-dose methotrexate, vincristine, mitomycin $\mathrm{C}$, doxorubicin, dacarbazine and cyclophosphamide (16); (iii) cyclophosphamide, doxorubicin, and methotrexate (7); (iv) vincristine, doxorubicin, cyclophosphamide, etoposide, ifosfamide and doxorubicin (5, 10, 19, 20); (v) vincristine, doxorubicin, cyclophosphamide and actinomycin D (21); (vi) cisplatin with doxorubicin or epirubicin or etoposide (13).

High-dose CT with busulfan and melphalan as consolidation treatment before WLI was used by Luksch and colleagues (15) and Paulussen and co-authors (5). Three studies reported a single agent regimen using actinomycin D (11) or doxorubicin $(14,17)$. One study did not mention the use of CT (8).

Surgery. Metastasectomy of lung nodules was performed before WLI in 2 studies $(5,15)$. In 2 studies it was not specified if surgery was performed before or after $\operatorname{WLI}(7,19)$. Improved OS was reported after metastasectomy in one study $(p=0.0002)$ (7) while EFS was similar in patients with or without pulmonary surgery $(p=0.411)$ in another study (5). 


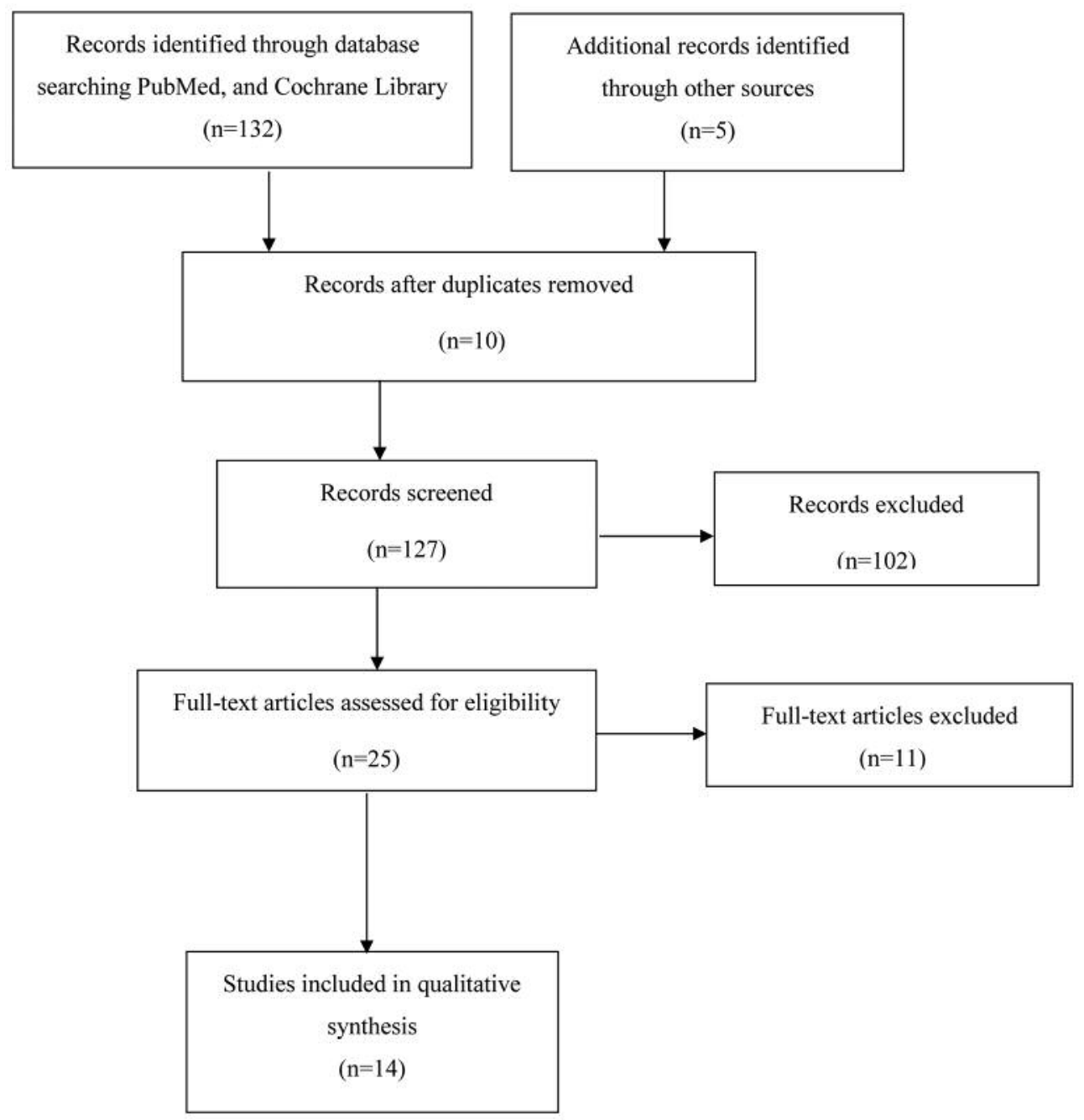

Figure 1. Process of article selection.

Toxicity. All but one paper (10) analyzed toxicity (640 patients). Table I shows the toxicity results in more details. Reported lung acute toxicity grade $\geq 3$ ranged between 0.0 and $12.2 \%(5,7,8,10,11,13-16,18-21)$. Toxicity scales were not reported in all but 2 studies $(7,18)$. From our analysis, clinical mild and moderate dyspnea and cough were reported in 6 studies including $29(4.5 \%)$ patients $(5,15,16$, 18-20). Three studies reported 12 cases $(1.8 \%)$ of severe pneumonitis $(5,15,19)$. In 2 studies increased toxicity compared to the rest of the study population were reported in active smoker patients $(16,20)$. No skeletal deformities or growth retardation were reported in any paper.

Pulmonary Function Tests. PFTs were performed in 10 studies including 217 patients $(5,7,14-21)$ (Table I). Normal tests were reported in 3 studies ranging between 40.5 and $100 \%$ $(17,19,21)$. Restrictive disorders were reported in 6 studies ranging from 19.0 to $100 \%(5,14-16,18,20)$. Late lung function impairment was reported in one study in $14.3 \%$ of patients (7) and one study recorded severe impairment in $10.8 \%$ of patients (19). None of the studies reported the used modalities and timing to evaluate lung impairment. In 3 studies $(5,8,15)$ only partial data were reported regarding PFTs. Breur and co-workers stated that PFTs were optional and performed only in a small number of patients in whom no clinical evidence of decreased pulmonary function was found (8). In one series with 75 patients, restrictive lung disease was reported in $7(9.3 \%)$ patients and one case of restrictive defect with less than $50 \%$ of vital capacity was reported in $1(1.3 \%)$ patient who received RT boost (5). In another series with 70 patients, 3 restrictive syndromes three months after WLI were recorded as severe and moderate in 1 and 2 patients, respectively. The authors reported a preexisting mild restrictive syndrome worsening after WLI in 1 case (15). 
Table I. Toxicity.

\begin{tabular}{|c|c|c|c|c|c|c|c|c|c|c|}
\hline $\begin{array}{l}\text { Authors } \\
\text { (year) }\end{array}$ & $\begin{array}{l}\text { Medical } \\
\text { center }\end{array}$ & $\begin{array}{c}\text { WLI } \\
\text { patients }\end{array}$ & $\begin{array}{l}\text { Median } \\
\text { dose, Gy } \\
\text { (Gy/Fract) }\end{array}$ & $\begin{array}{l}\text { Boost } \\
\text { N (Gy) }\end{array}$ & $\begin{array}{l}\text { Chest/lung } \\
\text { surgery N }\end{array}$ & Chemotherapy & $\begin{array}{l}\text { Pulmonary } \\
\text { function } \\
\text { tests } \mathrm{N} \\
\mathrm{n} \text { results }\end{array}$ & $\begin{array}{l}\text { Pulmonary } \\
\text { function } \\
\text { tests } \% \\
\text { toxicity } \%\end{array}$ & $\begin{array}{l}\text { Risk } \\
\text { factors } \\
\text { related to } \\
\text { lung }\end{array}$ & $\begin{array}{l}\text { Lung } \\
\text { acute } \\
\text { toxicity } \\
\mathrm{G} \geq 3 \%\end{array}$ \\
\hline $\begin{array}{l}\text { Rab } \\
(1976)(11)\end{array}$ & $\begin{array}{c}\text { Mayo Clinic, } \\
\text { Rochester, USA }\end{array}$ & 26 & $15(1.5)$ & 0 & 0 & $\mathrm{~A}$ & n.r. & n.r. & n.r. & 0.0 \\
\hline $\begin{array}{l}\text { Breur } \\
(1978)(8)\end{array}$ & $\begin{array}{c}\text { A. van Leeuwenhoek } \\
\text { Hospital, } \\
\text { Amsterdam, } \\
\text { The netherlands }\end{array}$ & 44 & $\begin{array}{c}17.5 \\
(1.75)\end{array}$ & 0 & 0 & No & n.r. & n.r. & n.r. & 0.0 \\
\hline $\begin{array}{l}\text { Razek } \\
(1980)(10)\end{array}$ & $\begin{array}{c}\text { Radiation } \\
\text { Oncology, } \\
\text { Washington, USA }\end{array}$ & 56 & $\begin{array}{c}15 \\
(1.5)\end{array}$ & 0 & 0 & V-A-C +/- D & n.r. & n.r. & n.r. & n.r. \\
\hline $\begin{array}{l}\text { Jasmin } \\
(1982)(16)\end{array}$ & $\begin{array}{c}\text { Hopital Paul } \\
\text { Brousse, } \\
\text { France }\end{array}$ & 21 & $\begin{array}{c}17.5 \\
(1.75)\end{array}$ & 0 & 0 & $\begin{array}{l}\text { MTX-V-M; } \\
\text { D-C; Da }\end{array}$ & 21 & $\begin{array}{c}\text { Restrictive: } \\
19.0 \\
\end{array}$ & $\begin{array}{l}\text { Smoker: } \\
\quad 4.8 \\
\text { Polychemo- } \\
\text { therapy } \\
+ \text { WLI: } 4.8\end{array}$ & 0.0 \\
\hline $\begin{array}{l}\text { Zaharia } \\
(1986)(17)\end{array}$ & $\begin{array}{c}\text { Instituto Nacional } \\
\text { Neoplasicas, } \\
\text { Lima, Perù }\end{array}$ & 36 & $20(1.5)$ & 0 & 0 & $\mathrm{D}$ & 6 & Normal: 100 & n.r. & 0.0 \\
\hline $\begin{array}{l}\text { Trifaud } \\
(1988)(18)\end{array}$ & $\begin{array}{c}\text { French Bone } \\
\text { Tumor Study } \\
\text { Group, France }\end{array}$ & 41 & $20(2)$ & 0 & 0 & $\begin{array}{l}\text { M-C-V- } \\
\text { MTX; V-Da }\end{array}$ & 41 & Normal: 0.0 & n.r. & 12.2 \\
\hline $\begin{array}{l}\text { Burgers } \\
\text { (1988) (7) }\end{array}$ & $\begin{array}{l}\text { Netherlands Cancer } \\
\text { Institute, Amsterdam, } \\
\text { The Netherlands }\end{array}$ & 140 & $20(2)$ & 0 & 0 & C-D-V-MTX & 56 & $\begin{array}{c}\text { Late lung } \\
\text { function } \\
\text { impairment: } \\
14.3\end{array}$ & n.r. & 0.0 \\
\hline $\begin{array}{l}\text { Ellis } \\
(1992)(14)\end{array}$ & $\begin{array}{c}\text { University of } \\
\text { Florida College } \\
\text { of Medicine, } \\
\text { Gainesville, USA }\end{array}$ & 57 & $16(1.6)$ & 0 & 0 & $\mathrm{D}$ & 28 & $\begin{array}{c}\text { Restrictive: } \\
100\end{array}$ & n.r. & 0.0 \\
\hline $\begin{array}{l}\text { Pochanugool } \\
\text { (1997) (13) }\end{array}$ & $\begin{array}{c}\text { Ramathibodi } \\
\text { Hospital Mahidad } \\
\text { University, } \\
\text { Bangkok, Thailand }\end{array}$ & 36 & $\begin{array}{l}24.8^{\S} \\
\text { (n.r.) }\end{array}$ & 0 & 0 & $\begin{array}{c}\mathrm{C}+\mathrm{D} \text { or } \mathrm{E} \\
\text { or Epirubicin }\end{array}$ & n.r. & 0.0 & n.r. & 0.0 \\
\hline $\begin{array}{l}\text { Paulussen } \\
\text { (1998) (5) }\end{array}$ & $\begin{array}{l}\text { Munster } \\
\text { University, } \\
\text { Germany }\end{array}$ & 75 & $\begin{array}{c}15-18 * \\
\text { (n.r.) }\end{array}$ & $1(45)$ & 20 & $\begin{array}{c}\text { BuMel; } \\
\text { V-D-C-A-E }\end{array}$ & 8 & Restrictive: 100 & n.r. & 5.3 \\
\hline $\begin{array}{l}\text { Bolling } \\
(2008)(19)\end{array}$ & $\begin{array}{l}\text { Munster } \\
\text { University, } \\
\text { Germany }\end{array}$ & 70 & $\begin{array}{c}12-21 * \\
(1.5)\end{array}$ & $\begin{array}{c}13 \\
(50-54)\end{array}$ & 12 & $\begin{array}{l}\text { V-D-I-A } \\
\text { E-V-D-I-A }\end{array}$ & 37 & $\begin{array}{l}\text { Normal: } 40.5 \\
\text { Mild: } 24.4 \\
\text { Moderate: } 21.6 \\
\text { Severe: } 10.8\end{array}$ & $\begin{array}{l}\text { Thoracic } \\
\text { surgery: } \\
66.7\end{array}$ & 7.1 \\
\hline $\begin{array}{l}\text { Luksch } \\
(2012)(15)\end{array}$ & $\begin{array}{c}\text { Italian and } \\
\text { Scandinavian, } \\
\text { Sarcoma Group }\end{array}$ & 57 & $15.0(1.5)$ & 0 & 6 & V-D-C-E-BuMel & 4 & $\begin{array}{c}\text { Restrictive: } \\
100\end{array}$ & n.r. & 1.8 \\
\hline $\begin{array}{l}\text { Casey } \\
(2014)(20)\end{array}$ & $\begin{array}{l}\text { Sloan Kettering } \\
\text { Cancer Center, } \\
\text { New York, USA }\end{array}$ & 26 & $15(1.5)$ & $\begin{array}{l}2(45) \\
1(21)\end{array}$ & 1 & V-D-C-I-E & 5 & $\begin{array}{c}\text { Restrictive: } \\
20.0 \\
\text { Reductions } \\
\text { residual } \\
\text { volume: } 40.0 \\
\text { Interstitial } \\
\text { disorder: } 40.0\end{array}$ & $\begin{array}{c}\text { Smokers: } \\
73.0 \\
\text { Non- } \\
\text { smokers: } \\
36.0\end{array}$ & 0.0 \\
\hline $\begin{array}{l}\text { Marinova } \\
(2015)(21)\end{array}$ & $\begin{array}{c}\text { Medical } \\
\text { University, } \\
\text { Varna, Bulgaria }\end{array}$ & 11 & $12-15 *$ (n.r.) & 0 & 0 & V-A-C-D & 11 & Normal: 100 & n.r. & 0.0 \\
\hline
\end{tabular}

A: Actinomycin; BuMel: busulfan and melphalan; D: doxorubicin; Da: dacarbazine; E: etoposide; I: ifosfamide; LT: lung toxixity, M: mitomycin C; MTX: methotrexate; V: vincristine; m: months; N: number of patients; n.r.: not reported; Ref: Reference; *dose given in range only; §mean dose. 
Table II. Outcome in studies on prophylactic WLI in osteosarcoma.

\begin{tabular}{|c|c|c|c|c|c|c|c|c|}
\hline $\begin{array}{l}\text { Authors } \\
\text { (year) }\end{array}$ & $\begin{array}{l}\text { Medical } \\
\text { center }\end{array}$ & $\begin{array}{l}\text { Number } \\
\text { of } \\
\text { patients }\end{array}$ & $\begin{array}{l}\text { Median } \\
\text { age } \\
\text { (years) }\end{array}$ & $\begin{array}{c}\text { Median WLI } \\
\text { dose (Gy) } \\
\text { (fractionation) }\end{array}$ & Chemotherapy & $\begin{array}{l}\text { Event- } \\
\text { free } \\
\text { survival }\end{array}$ & $\begin{array}{l}\text { Pulmonary } \\
\text { relapse } \\
\text { rate }\end{array}$ & $\begin{array}{l}\text { Overall } \\
\text { survival }\end{array}$ \\
\hline $\begin{array}{l}\text { Jasmin } \\
(1982)(16)\end{array}$ & $\begin{array}{c}\text { Hopital Paul } \\
\text { Brousse, } \\
\text { France }\end{array}$ & 21 & 15 & $17.5(1.75)$ & MTX-V- M-D & $16 \mathrm{~m}: 80 \%$ & $11 \mathrm{~m}^{*}: 11.1 \%$ & $16 \mathrm{~m}: 90 \%$ \\
\hline \multirow[t]{2}{*}{$\begin{array}{l}\text { Zaharia } \\
(1986)(17)\end{array}$} & $\begin{array}{l}\text { Instituto Nacional } \\
\text { Enfermedades }\end{array}$ & 29 & 15.3 & $20.0(1.5)$ & $\mathrm{D}$ & $372 \mathrm{~d}^{*}$ & n.r. & $843 \mathrm{~d}^{*}$ \\
\hline & $\begin{array}{c}\text { Neoplasicas, } \\
\text { Lima, Perù }\end{array}$ & 6 & 15.3 & $20.0(1.5)$ & no & $118 \mathrm{~d}^{*}$ & n.r. & $241 \mathrm{~d}^{*}$ \\
\hline $\begin{array}{l}\text { Trifaud } \\
\text { (1988) (18) }\end{array}$ & $\begin{array}{l}\text { French Bone } \\
\text { Tumor Study } \\
\text { Group, France }\end{array}$ & 41 & $18-23$ & $20.0(2.0)$ & $\begin{array}{l}\text { M-C-V-MTX } \\
\text { V-Da }\end{array}$ & $\begin{array}{l}1 \text { y: } 87 \% \\
2 \text { y: } 70 \% \\
3 \text { y: } 58 \%\end{array}$ & $\begin{array}{l}60.6 \mathrm{~m} *: \\
100 \%\end{array}$ & $\begin{array}{l}1 \text { y: } 95 \% ; \\
2 \text { y: } 75 \% ; \\
3 \text { y: } 61 \%\end{array}$ \\
\hline
\end{tabular}

A: Actinomycin; D: doxorubicin; C: cyclophosphamide; MTX: methotrexate; M: mitomycin; n.r: not reported; V: vincristine; Da: Dacarbazine; d: days; m: months; y: years; *median.

During follow-up no further impairment deterioration in pulmonary function was detected (15).

\section{Outcome measurements}

Outcome in studies on prophylactic WLI in osteosarcoma. Six studies reported EFS and OS after WLI with prophylactic intent in patients with $\operatorname{OSa}(7,8,11,16-18)$. Three studies were randomized trials and they will be analyzed later $(7,8,11)$. Three papers are analyzed in this paragraph (Table II).

In the report of Jasmin with a median follow up of 16 months, EFS and OS were $80 \%$ and $90 \%$, respectively and PRR was $11.1 \%$ (16).

Zaharia and coworkers reported 118 days median EFS in patients treated with WLI alone and 372 days in patients treated with WLI and CT $(p \leq 0.003)$. Furthermore, OS was significantly better in the group treated with CT and WLI (median: 843 days) compared to the group treated with WLI alone (median: 241 days) $(p<0.03)(17)$.

Trifaud and colleagues reported $87 \%, 70 \%$ and $58 \%$ of patients had 1-, 2-, and 3-year EFS, respectively and 95\%, $75 \%, 61 \%$ of patients had 1-, 2-, and 3-year OS, respectively. The authors reported that all patients experienced pulmonary relapse at a median time of 60.6 months. In the same study, multiparametric analyses revealed age as a significant prognostic factor for patients younger than 15 years old. Five-year OS was observed in $41 \%$ of patients younger than 15 years old and in $75 \%$ of patients older than 15 years old $(p<0.001)(18)$.

Outcome in studies on prophylactic WLI in Ewing Sarcoma. Two papers reported patients' outcome after prophylactic WLI in ESa $(10,21)$ : one randomized trial (10) [described in next paragraph] and 1 retrospective study (21). Marinova and co-workers reported 3- and 5-year EFS in $40 \%$ and $34 \%$ of patients, respectively. The authors also reported that 7 patients out of 11 who underwent prophylactic WLI were alive without lung metastases at a follow-up between 5 and 12 years. In this study WLI was for patients who had achieved primary tumor local control (21).

Outcome in studies on curative WLI in Ewing Sarcoma. Four studies reported outcome after curative WLI in ESa $(5,15$, 19, 20) (Table III). In the study of Paulussen and colleagues, 5-year EFS in patients treated with neoadjuvant therapy and local treatment of the primary tumor with WLI and without WLI was $38 \%$ vs. $27 \%$ ( $p=0.0022)$, respectively. Five-year OS was $46 \%$ for both groups and PRR was $40 \%$ in patients who did not receive WLI and $20 \%$ after WLI $(p=0.046)(5)$.

Bolling and co-workers reported 5-year EFS in 39\% of patients who received also WLI and $37 \%$ in patients without WLI ( $p=$ n.s.). After exclusion of patients with progressive disease before the start of the scheduled therapy, 5-year OS was $61 \%$ in patients treated with WLI vs. $49 \%$ in patients without WLI $(p=0.363)$. At 5-years, PPR occurred in $48.5 \%$ of patients receiving WLI vs. $38.8 \%$ in patients without WLI $(p=0.46)$ (19).

Luksch and co-authors reported 53\% and 66\% 5-year EFS and OS, respectively in patients who received WLI combined with high dose CT with busulfan and melphalan (HDCT) schedule. They reported 13 months median time to progression and identified negative prognostic factors emerging from multivariate analysis as: unfavorable histology, unfavorable radiological response at the site of primary tumor and incomplete radiological remission of lung metastases after primary CT (15). 
Table III. Outcome of studies on curative WLI Ewing Sarcoma.

\begin{tabular}{|c|c|c|c|c|c|c|c|c|}
\hline $\begin{array}{l}\text { Authors } \\
\text { (year) }\end{array}$ & Center & $\begin{array}{l}\text { Number } \\
\text { of } \\
\text { patients }\end{array}$ & $\begin{array}{l}\text { Median } \\
\text { age } \\
\text { (years) }\end{array}$ & $\begin{array}{c}\text { Median dose } \\
\text { (Gy) } \\
\text { (fractionation } \\
\text { Gy) }\end{array}$ & Chemotherapy & $\begin{array}{c}\text { Event-free } \\
\text { survival } \\
\text { (5-year) } \%\end{array}$ & $\begin{array}{l}\text { Pulmonary } \\
\text { relapse } \\
\text { (years) } \%\end{array}$ & $\begin{array}{c}\text { Overall } \\
\text { survival } \\
\text { (5-year) } \%\end{array}$ \\
\hline \multirow[t]{2}{*}{$\begin{array}{l}\text { Paulussen } \\
\text { (1998) (5) }\end{array}$} & $\begin{array}{c}\text { Munster University, } \\
\text { Germany }\end{array}$ & 75 & 15 & $\begin{array}{c}15-18 * \\
\text { (n.r.) }\end{array}$ & $\begin{array}{l}\text { V-D-Dac-C; } \\
\text { V-D-I-Dac; } \\
\text { E-V-D-I-A; } \\
\text { vs. V-D-I-A }\end{array}$ & 38.0 & $5 \mathrm{y}: 40.0$ & 46.0 \\
\hline & & 39 & 15 & No & $\begin{array}{l}\text { V-D-C-A; V-D-I-A } \\
\text { E-V-D-I-A; V-D-I-A }\end{array}$ & 27.0 & $5 \mathrm{y}: 20.0$ & 46.0 \\
\hline \multirow{4}{*}{$\begin{array}{l}\text { Bolling } \\
(2008)(19) \\
\text { Luksch } \\
(2012)(15)\end{array}$} & Munster University, & 70 & 15 & $12-21(1.5)$ & V-D-I-A+/-E & 39.0 & $5 \mathrm{y}: 48.5$ & 61.0 \\
\hline & Germany & 27 & 15 & No & V-D-I-A+/-E & 37.0 & $5 \mathrm{y}: 38.8$ & 49.0 \\
\hline & $\begin{array}{l}\text { Italian Sarcoma } \\
\text { Group and }\end{array}$ & 57 & 16 & $15(1.5)$ & V-D-I-E; BuMel & 53.0 & n.r. & 66.0 \\
\hline & $\begin{array}{c}\text { Scandinavian } \\
\text { Sarcoma Group }\end{array}$ & 45 & 16 & $15(1.5)$ & V-D-I-E & 43.0 & n.r. & 52.0 \\
\hline $\begin{array}{l}\text { Casey } \\
(2014)(20)\end{array}$ & $\begin{array}{c}\text { Sloan Kettering } \\
\text { Cancer Center, } \\
\text { New York, USA }\end{array}$ & 26 & 23 & $15(1.5)$ & V-D-C-I-E & $3 y: 38.0$ & $3 \mathrm{y}: 55.0$ & $3 y: 45.0$ \\
\hline
\end{tabular}

A: Actinomycin; BuMel: busulfan and melfalan; C: ciclophosphamide; D: doxorubicin; Dac: dactinomycin; E: etoposide; I: ifosfamide; n.r: not reported; V: vincristine; y: year; *: dose given in range only.

In the paper published by Casey and co-authors, 3-year EFS, OS and PPR were $38 \%, 45 \%$ and $55 \%$, respectively. In the same paper, patients with exclusively pulmonary metastases had better outcomes compared to patients with extra-pulmonary disease. EFS was $61 \%$ in non-smokers versus $11 \%$ in smokers $(p=0.04)$. The authors also reported that patients who received 15 Gy WLI had an OS of $51 \%$ compared to $25 \%$ in those who received $12-13$ Gy (20).

Outcome in randomized trials. Five randomized trials on prophylactic WLI in both ESa and OSa reporting EFS and OS have been published (Table IV).

$\mathrm{Rab}$ and co-workers enrolled 53 patients with localized OSa in two arms to compare adjuvant doxorubicin plus WLI versus a control group (no adjuvant therapy). The authors reported a median EFS of 18 months for both arms while median OS was 42 months for patients who got WLI plus CT vs. 25 months for the patients without adjuvant therapy $(p=\mathrm{n} . \mathrm{s})$. Two-year EFS and OS probability in the WLI plus CT and without adjuvant therapy were $42 \%$ vs. $38 \%$, and $60 \%$ vs. $52 \%$, respectively (11).

In 1978, Breur and colleagues (8) performed a multicenter study reporting $43 \%$ and $28 \%, 5$-year EFS, respectively in patients with OSa treated with or without WLI $(p=0.028)$. Five-year OS in patients treated with or without WLI was $55 \%$ and $40 \%$, respectively ( $p=0.059)$. With 2 to 6 years of follow up, PRR in patients treated with and without WLI was $18.2 \%$ and $9.5 \%$, respectively. In the same study, patients younger than 17 years old had 5-year metastases free survival of $48 \%$ and $28 \%$ if treated with or without WLI, respectively $(p=0.028)$. Moreover, 5-year OS in patients under 17 years of age was 59\% and $35 \%$ if treated with or without WLI, respectively ( $p=0.052)(8)$.

Razek and colleagues published the results of a randomized trial comparing different treatment regimens for primary ESa: vincristine, actinomicin and cyclophosphamide (VAC) plus adriamycin (regimen I), VAC alone (regimen II), and VAC combined with WLI (regimen III). With median follow up of 83 weeks, EFS was $96 \%, 86 \%$ and $86 \%$, respectively ( $p=$ n.s.). With a median follow up of 172 weeks, OS was $78 \%, 38 \%$, and $55 \%$, respectively. The $p$-value was 0.1 , for regimen I $v s$. regimen II, 0.16 for regimen II $v s$. regimen III, and 0.61 for regimen I $v s$. regimen III. Adriamycin-VAC was superior to WLI-VAC in terms of OS. The authors reported that the addition of adriamycin to VAC in regimen I decreased the incidence of pulmonary metastases to $10 \%$ while in patients treated with VAC alone the incidence was $38 \%(p=0.001)$. Furthermore, WLI in regimen III reduced the incidence of pulmonary metastases to $20 \%(p<0.10)(10)$.

Burgers and colleagues reported the results of an EORTC randomized study stopped earlier due to the development of new promising multi-drug CT. They randomly compared 3 arms: CT, WLI, and both (CT plus WLI) in OSa. Four-year EFS and OS were $24 \%$ and $43 \%$, respectively in all arms $(p=0.76)$ and 5-year PRR was 62\% in the three arms (7).

Pochanugool and coworkers prospectively randomized 130 patients with OSa of whom 36 received 22.5 to $27 \mathrm{~Gy}$ WLI in 6-16 weeks concomitant to postoperative CT. The 2- 
Table IV. Randomized trials on prophylactic WLI.

\begin{tabular}{|c|c|c|c|c|c|c|c|c|c|}
\hline $\begin{array}{l}\text { Authors } \\
\text { (year) }\end{array}$ & $\begin{array}{l}\text { Medical } \\
\text { center }\end{array}$ & $\begin{array}{l}\text { Number } \\
\text { of } \\
\text { patients }\end{array}$ & $\begin{array}{l}\text { Inclusion } \\
\text { criteria } \\
\text { (mean age) }\end{array}$ & Chemotherapy & $\begin{array}{c}\text { Median WLI } \\
\text { dose (Gy) } \\
\text { (fractionation) }\end{array}$ & $\begin{array}{c}\text { Event- } \\
\text { free } \\
\text { survival } \%\end{array}$ & $\begin{array}{l}\text { Pulmonary } \\
\text { relapse } \% * \\
\text { median FU }\end{array}$ & $\begin{array}{c}\text { Overall } \\
\text { survival } \%\end{array}$ & $p$-Value \\
\hline \multirow[t]{2}{*}{$\begin{array}{l}\text { Rab } \\
(1976)(11)\end{array}$} & $\begin{array}{c}\text { Mayo Clinic, } \\
\text { Rochester, USA }\end{array}$ & 26 & OSa (15) & $\mathrm{D}$ & $15(1.5)$ & $18 \mathrm{~m}^{*}$ & $18 \mathrm{~m}: 65.0$ & $42 \mathrm{~m} *: 54.0$ & $p=\mathrm{n} . \mathrm{s}$ \\
\hline & & 27 & OSa (16.9) & No & No & $18 \mathrm{~m} *$ & $18 \mathrm{~m}: 59.0$ & $25 \mathrm{~m}^{*}: 48.0$ & \\
\hline \multirow{2}{*}{$\begin{array}{l}\text { Breur } \\
(1978)(8)\end{array}$} & A. van & 44 & OSa $(<60)$ & No & $17.5(1.75)$ & $\geq 2 \mathrm{y}: 43.0$ & $\geq 2 \mathrm{y}: 18.2$ & $>4 y: 55.0$ & $p=0.18$ \\
\hline & $\begin{array}{l}\text { Leeuwenhoek } \\
\text { Hospital, } \\
\text { Amsterdam, } \\
\text { The Netherlands }\end{array}$ & 42 & OSa $(<60)$ & No & No & $\begin{array}{l}\geq 2 \mathrm{y}: 28.0 \\
p=0.028\end{array}$ & $\geq 2 y: 9.5$ & $>4 y: 40.0$ & \\
\hline \multirow{3}{*}{$\begin{array}{l}\text { Razek } \\
(1980)(10)\end{array}$} & $\begin{array}{l}\text { Radiation } \\
\text { Oncology, }\end{array}$ & 73 & ESa & V-A-C-D (X) & No & $83 w: 96.0$ & 83 w*: 10.0 & $172 \mathrm{w}^{*}: 78.0$ & $\begin{array}{c}\mathrm{X} \text { vs. Y: } \\
p=0.10\end{array}$ \\
\hline & Washington, USA & 64 & ESa & V-A-C (Y) & No & $83 w: 86.0$ & $83 w^{*}: 38.0$ & $172 \mathrm{w}^{*}: 38.0$ & $\begin{array}{l}\mathrm{Y} \text { vs. Z: } \\
p=0.16\end{array}$ \\
\hline & & 56 & ESa & V-A-C (Z) & $15(1.5)$ & $83 w: 86.0$ & $83 \mathrm{w}^{*}: 20.0$ & $172 w^{*}: 55.0$ & $\begin{array}{l}\mathrm{X} v s . \mathrm{Z}: \\
p=0.61\end{array}$ \\
\hline \multirow{2}{*}{$\begin{array}{l}\text { Burgers } \\
\text { (1988) (7) }\end{array}$} & Netherlands & 67 & OSa (1-16) & V-D-MTX & $20(2.0)$ & $4 y: 24.0$ & $5 y: 62.0$ & $4 y: 43.0$ & $p=0.76$ \\
\hline & $\begin{array}{l}\text { Cancer Institute, } \\
\text { Amsterdam, } \\
\text { The Netherlands }\end{array}$ & $\begin{array}{l}65 \\
73\end{array}$ & $\begin{array}{l}\text { OSa }(1-16) \\
\text { OSa }(1-16)\end{array}$ & $\begin{array}{l}\text { V-D-MTX } \\
\text { No }\end{array}$ & $\begin{array}{c}\text { No } \\
20(2.0)\end{array}$ & & & & \\
\hline \multirow{2}{*}{$\begin{array}{l}\text { Pochanugool } \\
\text { (1997) (13) }\end{array}$} & Ramathibodi & 36 & OSa & $\mathrm{C}-\mathrm{D} / \mathrm{E}$ & 24.8 (n.r.) & n.r. & 16.0 & $9 y: 70.0$ & $p=0.05$ \\
\hline & $\begin{array}{c}\text { hospital, } \\
\text { Mahidad } \\
\text { University, } \\
\text { Bangkok, Thailand }\end{array}$ & 79 & OSa & $C-D / E$ & No & n.r. & $49.0 \mathrm{p}=0.009$ & $9 y: 46.0$ & \\
\hline
\end{tabular}

A: Actinomycin; C: cisplatin; D: doxorubicin; E: etoposide; ESa: Ewing sarcoma; FU: follow-up; MTX: methotrexate; n.r: not reported; n.s: not significant; OSa: osteosarcoma; V: vincristine; w: weeks; y: years, *median.

, 3-, 5- and 9-year survival rates of the whole group were $76 \%, 65 \%, 55 \%$ and $55 \%$ respectively. Thirty-six patients treated with prophylactic WLI had a 9-year survival rate of $70 \%$ compared to $46 \%$ in 79 patients who did not receive WLI $(p=0.05)$. The incidence of lung metastases was lower in the irradiated group. In fact, $16 \%$ and $49 \%$ developed lung metastases in the WLI arm and in the arm without WLI, respectively $(p=0.009)(13)$.

\section{Discussion}

Lungs are radio-sensitive organs particularly in the case of large irradiated volumes. In fact, the mean doses that are correlated to a risk of $13 \%$ and $20 \%$ of symptomatic pneumonitis are only 10 and $20 \mathrm{~Gy}$, respectively. For this reason, WLI is a challenging treatment for radiation oncologists due to the tight constraints for lung irradiation.

Despite this marked lung sensitivity, the incidence of severe pulmonary complications seemed relatively low in our analysis. One reason for this positive outcome could be the relatively homogeneous irradiation of the lungs without volumes receiving relatively high doses. Another reason could be the relatively short follow-up in most studies particularly in phase II trials or the non-systematic and nonprospective, in the case of retrospective studies, toxicity assessments. Moreover, different types of mild to intermediate lung damage were described with variable incidences in individual studies that could probable be attributed to underestimation given the limited use of PFT.

Our analysis has clear limits related to the different study designs, lack of treatment homogeneity in terms of both integrations with surgery, CT, and RT doses and fractionation. Furthermore, the inclusion criteria are inhomogeneous in particular with regard to age. Overall, only 3 out of the 14 analyzed studies were considered at low risk of bias.

In terms of toxicity, it can be observed that although the median incidence of severe $(\mathrm{G} \geq 3)$ pulmonary toxicity was $0 \%$, some authors reported incidences above $5 \%(5,18,19)$. In addition, other authors reported lung impairments mainly of a restrictive type based on PFTs with a prevalence of $100 \%(5,14-16)$. The negative impact of CT (16), thoracic surgery (19) and smoking habits $(16,20)$ were reported sporadically. The actual impact of these factors is unclear considering the lack of evaluation in studies not reporting on these relationships. The impact of dose and fractionation are not evident based on our analysis. In particular, the highest 
incidence of severe pulmonary side-effects (12.2\%) was recorded in the study of Trifaud and collaborators (18) who administered $20 \mathrm{~Gy}$ in 2 Gy fractions in their series of 41 patients. In contrast, Burger and colleagues (8) did not observe cases of severe toxicity in their series of 140 patients despite the delivery of the same dose and fractionation.

From the studies on prophylactic WLI in OSa, few conclusions can be drawn due to the lack of homogeneity in describing the results. The only evident aspect is the improvement of EFS and OS in patients undergoing WLI + CT compared to WLI alone as recorded in the study by Zaharia and colleagues (17). The efficacy of combination therapy in this setting was confirmed by the study of Trifauld and collaborators (18) who recorded a median survival of more than 3 years in patients who underwent WLI + CT.

In the series on curative WLI in ESa, it can be observed that only two studies compared patients who got CT alone with those who got both CT plus WLI $(5,19)$. In the first study, patients who got also WLI showed better results in terms of EFS (5-year: $38.0 \%$ vs. $27.0 \%$ ) and pulmonary relapse (5-year: $40.0 \%$ vs. $20.0 \%$ ) (5). In the second study, a $9.7 \%$ reduction of pulmonary relapse at 5 years and $12 \%$ improvement of 5-year OS were observed (19).

In the randomized studies on prophylactic WLI, we can observe that 4 of these involved patients with OSa. In all studies, an improvement of some end-points was observed in patients treated with WLI in particular EFS (8), Pulmonary Relapse $(13)$ and OS $(11,13)$. In the only study on ESa, WLI + VAC showed superior results compared to VAC alone in terms of pulmonary relapse and OS. However, regarding the same end-points, VACD alone was superior to WLI + VAC (10).

To summarize the results of this analysis, the risk of complications is at least non-negligible based on PFTs evaluation despite a minimum percentage of severe pneumonia. According to some sporadic reports, this risk is higher in some patients' categories and difficult to stratify the patients most susceptible to toxicity and clearly understand the relationship between dose and complications.

Concise evaluation of clinical outcomes picture is even more complex. Non-randomized studies indicate clear superiority of combination with CT in prophylactic WLI for OSa patients. Randomized trials show a positive impact on at least some end-points. In terms of survival, the Pochanugool study (13) showed a close to significant improvement in 9-year survival $(70.0 \%$ vs. $46.0 \% ; p=0.05)$. The Rab study (11) showed a similar improvement with median survival of 42 months $v s .25$ months. This difference was not significant probably due to the low number of patients (total: 53 patients). Similar considerations can be made regarding the Breur study (8) in which a $15 \%$ improvement in OS was not statistically significant probably also due to the analyzed patients size. Therefore, the use of prophylactic WLI in OSa can be justified especially in patients with greater risk of metastatic diffusion.

Regarding curative WLI for ESa patients with lung metastases, the results are substantially similar with several studies showing some improvement of the different endpoints. Also, in this case it could be reasonably concluded that the use of WLI can be justified especially in patients with higher risks to metastases.

The results of this treatment do not seem optimal due to the marginal impact on survival in most studies and the risk of toxicity. Therefore, the use of WLI should be individualized based on the risk of lung metastases and the presence of respiratory comorbidities. Furthermore, its use should be reserved for centers with considerable experience in the management of these patients and in particular of possible treatment related complications.

From a scientific point of view, it is evident that there is need to identify alternative treatments possibly less toxic and more effective especially in terms of OS and quality of life. For example, in oligometastatic lung patients, the combination of CT and stereotactic RT seems less toxic and more effective compared to CT plus WLI (22). This data requires further validation in prospective studies.

In patients treated with WLI for prophylactic purposes, the use of ultra-fractionated regimens (dose per fraction $<0.5 \mathrm{~Gy}$ ) administered concomitantly with CT could be tested as an alternative. In fact, RT is traditionally used with conventional fractionation (1.8-2 Gy/fraction). Lower fraction doses were found more effective than predicted by the linear-quadratic model (23). Survival curves for some irradiated cell populations show a steeper slope in the initial phase (between 0.0 and 0.5 Gy). This phenomenon is known as Hyper Radiation Sensitivity (HRS) and has been confirmed in several cell lines $(24,25)$ and in vivo studies (26). Moreover, some preclinical studies show that lower-fraction RT dose increases the biological efficacy of CT suggesting a synergistic effect between this fractionation modality and CT probably by increasing apoptosis and thus improving the global efficacy $(27,28)$. At the same time applying low total dose, very low RT dose per fraction and very prolonged treatment time (the same of CT) would be potentially less toxic. For all these reasons, the prophylactic treatment of lung metastases from ESa or OSa seems to be an ideal setting to test ultra-fractionated RT plus CT.

\section{Conflicts of Interest}

The Authors have no actual or potential conflicts of interest regarding this study.

The abstract has been previously presented as an oral poster at the 36th Annual meeting of the ESTRO (European Society for Radiotherapy \& Oncology), Vienna, Austria, May 5-9, 2017 and at Congresso AIEOP (Associazione Italiana di Oncoematologia Pediatrica) Bologna, Italy, May 27-29, 2018 as an oral communication. 


\section{References}

1 Siegel RL, Miller KD and Jemal A: Cancer Statistics, 2017. CA Cancer J Clin 67: 7-30, 2017.

2 Ries LAG, Smith MA, Gurney JG, Linet M, Tamra T, Young JL and Bunin GR (eds). Cancer incidence and survival among children and adolescents: United States SEER Program 19751995, National Cancer Institute, SEER Program. NIH Pub. No. 99-4649. Bethesda, MD, 1999.

3 Halperin EC, Wazer DE, Perez CA and Brady LW: Perez and Brady's Principles and Practice of Radiation Oncology. Sixth edition, Lippincott Williams and Wilkins., pp. 161, 2013

4 Margolis LW and Phillips TL: Whole lung irradiation for metastatic tumor. Radiology 93: 1173-1179, 1969.

5 Paulussen M, Ahrens S, Burdach S, Craft A, DockhornDworniczak B, Dunst J, Fröhlich B, Winkelmann W, Zoubek A and Jürgens H: Primary metastatic (stage IV) Ewing tumor: survival analysis of 171 patients from the EICESS studies. European Intergroup Cooperative Ewing Sarcoma Studies. Ann Oncol 9: 275-281, 1998.

6 Caldwell WL: Elective whole lung irradiation. Radiology 120: 659-666, 1976.

7 Burgers JM, van Glabbeke M, Busson A, Cohen P, Mazabraud AR, Abbatucci JS, Kalifa C, Tubiana M, Lemerle JS, Voûte PA et al: Osteosarcoma of the limbs. Report of the EORTC-SIOP 03 trial 20781 investigating the value of adjuvant treatment with chemotherapy and/or prophylactic lung irradiation. Cancer 61: 1024-1031, 1988.

8 Breur K, Cohen P, Schweisguth O and Hart AMM: Irradiation of the lungs as an adjuvant therapy in the treatment of osteosarcoma of the limbs. An EORTC randomized study. Cancer 14: 461-471, 1978.

9 Whelan JS, Burcombe RJ, Janinis J, Baldelli AM and Cassoni AM: A systematic review of the role of pulmonary irradiation in the management of primary bone tumours. Ann Oncol 13: 2330, 2002.

10 Razek A, Perez CA, Tefft M, Nesbit M, Vietti T, Burgert EO, Kissane J, Pritchard DJ and Gehan E: Intergroup Ewing's sarcoma study local control related to radiation dose, volume, and site of primary lesion in Ewing's sarcoma. Cancer 46: 516-521, 1980.

11 Rab GT, Ivins JC, Childs DS, Cupps RE and Pritchard DJ: Elective whole lung irradiation in the treatment of osteogenic sarcoma. Cancer 38: 939-942, 1976.

12 Moher D, Liberati A, Tetzlaff $\mathrm{J}$ and Altman DG: PRISMA Group.Preferred reporting items for systematic reviews and meta-analyses: the PRISMA statement. J Clin Epidemiol 62: 1006-1012, 2009.

13 Pochanugool L Subhadharaphandou T, Dhanachai M, Hathirat P, Sangthawan D, Pirabul R, Onsanit S and Pornpipatpong N: Prognostic factors among 130 patients with Osteosarcoma. Clin Orthop Relat Res 345: 206-214, 1997.

14 Ellis ER, Marcus RB Jr., Cicale MJ, Springfield DS, Bova FJ, Graham-Pole J, Enneking WF, Spanier SS and Million RR: Pulmonary function tests after whole-lung irradiation and doxorubicin in patients with osteogenic sarcoma. J Clin Oncol 10: 459-463, 1992.

15 Luksch R, Tienghi A, Hall KS, Fagioli F, Picci P, Barbieri E, Gandola L,Eriksson M, Ruggieri P, Daolio P, Lindholm P, Prete A, Bisogno G, Tamburini A, Grignani G, Abate ME, Podda M, Smeland S and Ferrari S: Primary metastatic Ewing's family tumors: results of the Italian Sarcoma Group and Scandinavian Sarcoma Group ISG/SSG IV Study including myeloablative chemotherapy and total-lung irradiation. Ann Oncol 23: 29702976, 2012.

16 Jasmin C: A Strategic Adjuvant therapy of osteosarcoma. Recent Results Cancer Res 80: 108-114, 1982.

17 Zaharia M, Caceres E, Valdivia S, Moran M and Tejada F: Postoperative whole lung irradiation with or without adriamycin in osteogenic sarcoma. Int J Radiation Oncology Biol Phys 12: 907-910, 1986.

18 French Bone Tumour Study Group. Age and dose of chemotherapy as major prognostic factors in a trial of adjuvant therapy of osteosarcoma combining two alternating drug combination and early prophilactic lung irradiation. Cancer 61: 1304-1311, 1988.

19 Bolling T, Schuck A, Paulussen M, Dirksen U, Ranft A, Konemann S, Dunst J, Willich N and Jurgens H: Whole lung irradiation in patients with exclusively pulmonary metastases of ewing tumors, toxicity analysis and treatment results of the EICESS-92 Trial. StrahlenterOnkol 184: 193-197, 2008.

20 Casey DL, Alektiar KM, Gerber NK and Wolden SL: Whole lung irradiation for adults with pulmonary metastases from Ewing sarcoma. Int J Radiation Oncol Biol Phys 89: 1069-1075, 2014.

21 Marinova L, Hristozova I, Mihaylova I and Perenovska P: Protective, elective lung irradiation in non-metastatic Ewing's sarcoma. Radiat Prot Dosimetry 165: 492-494, 2015.

22 Frakulli R, Salvi F, Balestrini D, Parisi A, Palombarini M, Cammelli S, Rocca M, Salone M, Longhi A, Ferrari S, Morganti AG and Frezza G: Stereotactic radiotherapy in the treatment of lung metastases from bone and soft-tissue sarcomas. Anticancer Res 35: 5581-5586, 2015.

23 Joiner MC, Marples B, Lambin P, Short SC and Turesson I: Low-dose hypersensitivity: current status and possible mechanisms. Int J Radiat Oncol Biol Phys 49: 379-389, 2001.

24 Marples B and Joiner MC: The response of Chinese hamster V79 cells to low radiation doses: evidence of enhanced sensitivity of the whole cell population. Radiat Res 133: 41-51, 1993.

25 Wouters BG, Sy AM and Skarsgard LD: Low-dose hypersensitivity and increased radioresistance in a panel of human tumor cell lines with different radiosensitivity. Radiat Res 146: 399-413, 1996.

26 Beauchesne PD, Pedeux RM, Bonmartin A, Bertrand S, Jouvet A, Kirchner AL, Revel R, Mornex F and Dore JF: Intracerebral C6 glioma model in female hairless rats: assessment by using MRI and follow-up of irradiation. Anticancer Res 23: 37553760, 2003.

27 Dey S, Spring PM, Arnold S, Valentino J, Chendil D, Regine WF, Mohiuddin M and Ahmed MM: Low-dose fractionated radiation potentiates the effects of Paclitaxel in wild-type and mutant p53 head and neck tumor cell lines. Clin Cancer Res 9: 1557-1565, 2003.

28 Gupta S, Koru-Sengul T, Arnold SM, Devi GR, Mohiuddin M and Ahmed MM: Low-dose fractionated radiation potentiates the effects of cisplatin independent of the hyper-radiation sensitivity in human lung cancer cells. Mol Cancer Ther 10: 292-302, 2011.

Received July 13, 2018

Revised August 9, 2018 Accepted August 10, 2018 